\title{
ARBUSCULAR MYCORRHIZAL FUNGUS IN MICROBIAL ACTIVITY AND AGGREGATION OF A CERRADO OXISOL IN CROP SEQUENCE
}

\author{
Fungo micorrízico arbuscular na atividade microbiana e agregação de um \\ Latossolo Vermelho de Cerrado submetido às sucessões de culturas
}

\author{
Laíze Aparecida Ferreira Vilela ${ }^{1}$, Orivaldo José Saggin Júnior ${ }^{2}$, Helder Barbosa Paulino ${ }^{3}$, \\ José Oswaldo Siqueira ${ }^{1}$, Vera Lúcia da Silva Santos ${ }^{4}$, Marco Aurélio Carbone Carneiro ${ }^{5}$
}

\begin{abstract}
Soil structure has major influence on ecosystem sustainability and plant growth. Arbuscular mycorrhizal fungi (AMF) are an important functional group of soil microbiota, acting in the process of aggregation, especially in agroecosystems and related to the production and plant diversity. AMF are widely distributed in tropical agroecosystems and are extremely important for development of many agricultural crops. The present study evaluated the effect of inoculation with Glomus macrocarpum in different crop sequences on plant growth, microbial activity and aggregation of a Cerrado Oxisol. The study was conducted in a completely randomized design in a 4 x 4 factorial scheme. Treatments consisted of four conditions of elimination and/or introduction of AMF (NS-NI: non-sterilized and non-inoculated; NS-I: non-sterilized and inoculated; S-NI: sterilized and non-inoculated; andS-I: sterilized and inoculated) and four crop sequences (Panicum maximum/Panicum maximum, Brachiaria ruziziensis/ soybean, sorghum/soybean and Stylosanthes spp./soybean). Inoculation favored growth of Stylosanthes spp. by increasing plant growth in up to $91 \%$ when inoculated. None of the grasses benefited from G. macrocarpum introduction. We observed that $G$. macrocarpum inoculation associated with indigenous AMF increased microbial biomass, phosphatase activity, mean geometric diameter and mean weighted diameter. The results indicated the beneficial effects of inoculation, which reflected in soil structure improvement and, hence, to agroecosystems sustainability.
\end{abstract}

Index terms: Microbial carbon, acid phosphatase, mean geometric diameter, mean weight diameter, soil structure.

\begin{abstract}
RESUMO
A estrutura do solo exerce importante influência na sustentabilidade dos ecossistemas e no crescimento de plantas. Os fungos micorrízicos arbusculares (FMAs) constituem um importante grupo funcional da microbiota do solo, atuando diretamente nos processos de agregação, principalmente em agroecossistemas e têm relação direta com a produção e diversidade vegetal. Esses estão amplamente distribuídos no agroecossistemas tropicais e são extremamente importantes para o crescimento de várias espécies vegetais agrícolas. No presente estudo, avaliou-se o efeito da inoculação com Glomus macrocarpum e diferentes sucessões de culturas no crescimento vegetal, na atividade microbiana e na agregação de um Latossolo Vermelho de Cerrado. O estudo foi conduzido em delineamento inteiramente casualizado com arranjo fatorial 4 x 4. Os tratamentos constituíram da combinação entre quatro condições de eliminação e/ou introdução de FMA (NS-NI: não autoclavado-não inoculado; NS-I: não autoclavado-inoculado; S-NI: autoclavado-não inoculado; S-I: autoclavado-inoculado) e quatro sucessões de culturas (Panicum maximum/Panicum maximum; Brachiaria ruziziensis/soja; sorgo/soja; Stylosanthes spp./soja). A inoculação com FMAs favoreceu o crescimento do estilosantes, apresentando aumento de até $91 \%$ na produção de massa seca quando inoculado. Nenhumas das gramíneas beneficiaram-se com a introdução de G. macrocarpum. Nós observamos que a inoculação com G. macrocarpum associado aos FMAs indígenas incrementou a biomassa microbiana, atividade da fosfatase ácida, diâmetro médio geométrico e o ponderado. Os resultados indicam os efeitos benéficos da inoculação que reflete na melhoria da estrutura do solo, contribuindo para a sustentabilidade.
\end{abstract}

Termos para indexação: Carbono da biomassa microbiana, fosfatase ácida, diâmetro médio geométrico, diâmetro médio ponderado, estrutura do solo.

\section{INTRODUCTION}

Arbuscular Mycorrhizal Fungi (AMF) belong to phylum Glomeromycota and play a role in soil structure formation and stabilization (Báez-Pérez et al., 2010;
Fokom et al., 2012). AMF are involved in soil aggregates formation and stabilization by developing a hyphae network, creating a structural skeleton that acts in the junction and adhesion of soil particles. AMF hyphae produce mucigel (glomalin) establishing appropriate

\footnotetext{
1Universidade Federal de Lavras/UFLA - Departamento de Ciência do Solo/DCS - Lavras - MG - Brasil

${ }^{2}$ Empresa Brasileira de Pesquisa Agropecuária/Embrapa-Agrobiologia - Seropédica - RJ - Brasil

3Universidade Federal de Goiás/UFG - Campus jataí - Jataí - GO - Brasil

${ }^{4}$ Universidade Federal Rural do Rio de Janeiro/UFRRJ - Seropédica - RJ - Brasil

5Universidade Federal de Lavras/UFLA-Departamento de Ciência do Solo/DCS - Cx. P. 3037 -37200-000 - Lavras - MG - Brasil - marcocarbone@dcs.ufla.br

Received in november 5, 2013 and approved in february 14, 2014
}

Ciênc. Agrotec., Lavras, v.38, n. 1, p.34-42, jan./fev., 2014 
conditions to development of roots, external hyphae and others microorganisms from rhizosphere and mycorhizosphere (González-Chávez et al., 2004; Rillig, 2004; Purin; Rillig, 2007).

AMF are important components of soil microorganisms, mainly in the agricultural ecosystems (Siqueira et al., 2000) and are related to production and plant diversity (Klironomos et al., 2000). Several studies in soils under Cerrado demonstrated the adverse effects of different management practices and land use in the diversity and density of AMF (Cordeiro et al., 2005; Ferreira; Carneiro; Saggin-Junior, 2012). Miranda, Vilela and Miranda (2005) observed that crop rotation favored multiplication of indigenous AMF, and these fungi contributed to the greater development of soybean and Panicum maximum in 53 and 95\%, respectively. Therefore, adoption of management systems associated with its known benefits over AMF association, will favor crop production aiding to maintain a better soil structure and soil quality(Johansson, Paul; Finlay, 2004).

AMF are widely spread in tropical agroecosystems (Stürmer; Siqueira, 2011) and are extremely important for growth of many agricultural crops. Thereby, further studies are needed to assess the effects of AMF in functionality and stability soils under different land uses. For that, the present study aimed to assess the effects of AMF inoculation in different crop sequences in microbial activity and aggregation of a Cerrado Oxisol.

\section{MATERIAL AND METHODS}

The study was conducted in greenhouse at Federal University of Goiás, in an Oxisol collected from the 0-10 $\mathrm{cm}$ layer in an area under no-till for ten years (soybean and corn succession). The soil textural and chemical characteristics were: $\mathrm{pH}$ (water) $=5,8 ; \mathrm{H}+\mathrm{Al}=5,01 \mathrm{cmol}_{\mathrm{c}}$ $\mathrm{dm}^{-3} ; \mathrm{Ca}^{2+}=1,37 \mathrm{cmol}_{\mathrm{c}} \mathrm{dm}^{-3} ; \mathrm{Mg}^{2+}=0,80 \mathrm{cmol}_{\mathrm{c}} \mathrm{dm}^{-3} ; \mathrm{K}^{+}$ $=87,46 \mathrm{mg} \mathrm{dm}^{-3} ; \mathrm{P}=1,50 \mathrm{mg} \mathrm{dm}^{-3} ; \mathrm{SOM}=26,77 \mathrm{~g} \mathrm{~kg}^{-1}$; sand $=228 \mathrm{~g} \mathrm{~kg}^{-1} ;$ silt $=165 \mathrm{~g} \mathrm{~kg}^{-1}$; clay $=607 \mathrm{~g} \mathrm{~kg}^{-1}$.

The experimental design was randomized in a $4 \mathrm{x}$ 4 factorial scheme with five replications. The treatments consisted of four conditions of elimination and/or introduction AMF in soil and four crop sequences. The soil treatments were NS-NI (non- sterilized and noninoculated soil), NS-I (non-sterilized and inoculated soil), S-NI (sterilized and non-inoculated soil) and S-I (sterilized and inoculated soil). The crop sequences were Panicum maximum/Panicum maximum, Brachiaria ruziziensis/soybean, sorghum/soybean and Stylosanthes spp./soybean).
The soil was sieved ( $2 \mathrm{~mm}$ mesh) and homogenized. The treatments S-NI and S-I were sterilized in autoclave for two consecutive days at $120^{\circ} \mathrm{C}$ for one hour. After autoclaving, the soil was stored for 15 days for chemical stabilization. The soil was placed in pots with capacity of $8 \mathrm{~kg}$. In order to increase base saturation to $50 \%$, soil was incubated with $7.5 \mathrm{~g} \mathrm{pot}^{-1}$ of limestone for 30 days.

In the initial evaluation of AMF community, 67 spores per $50 \mathrm{dm}^{3}$ of soil was extracted and identified as Acaulospora denticulata, Acaulospora scrobiculata, Acaulospora undulata, Ambispora leptoticha, Glomus macrocarpum, Glomus sp1, Glomus tortuosum and Gigaspora sp1, with higher proportions of Acaulospora scrobiculata, Acaulospora undulata and Gigaspora spl.

The first crops of the crop sequence were Panicum maximum, Brachiaria ruziziensis, sorghum (Sorghum bicolor) and Stylosanthes spp. Before sowing the first crops, pots were inoculated with Glomus macrocarpum Tul. \& C. Tul. We used this specie because it presented the highest occurrence frequency in the area, which the soil was collected (Ferreira; Carneiro; Saggin-Junior, 2012). Thus, this specie was isolated from the studied soil and multiplied in culture pots with Brachiaria ruziziensis during six months. The inoculated treatments received 50 $\mathrm{dm}^{3}$ of soil-inoculum placed under the seeds, supplying 2 spores $\mathrm{dm}^{-3}$ of soil-inoculum, hyphae and colonized roots of Brachiaria ruziziensis, which also act as mycorrhizal propagules. The non-inoculated soil received $50 \mathrm{dm}^{3}$ of filtrated from soil inoculum without mycorrhizal propagules.

The crop fertilization was applied according to soil analysis and the recommendation for each crop. So, were applied $\mathrm{N}, \mathrm{P}_{2} \mathrm{O}_{5}$ and $\mathrm{K}_{2} \mathrm{O}$ at ratios of 50,180 and $20 \mathrm{~kg} \mathrm{ha}^{-1}$ in Panicum maximum; 50, 90 and $60 \mathrm{~kg} \mathrm{ha}^{-1}$ in Brachiaria ruziziensis and 20, 60 and $40 \mathrm{~kg} \mathrm{ha}^{-1}$ in sorghum, 0, 60 and $60 \mathrm{~kg} \mathrm{ha}^{-1}$ in Stylosanthes spp. and soybean (Sousa; Lobato, 2004). Pots were irrigated to complete $60 \%$ of total pore volume with water, controlled by periodic weighing of pots.

At 180 days after sowing, shoots were cut and the second crop (soybean) was sown, except in the Panicum maximum treatment, which was allowed to resprout. Soybean seeds were inoculated with Bradyrhizobium japonicum (SEMIA 5080) and seeded, allowing developing three plants per pot. After 120 days of second crop cultivation, totaling 300 days, the study was finalized and soil samples were collected. Soil samples were subjected to extraction and counts of AMF spore, determination of the aggregation indexes, microbial biomass carbon, acid phosphatase activity and 
root samples to assess mycorrhizal colonization of soybean and Panicum maximum.

Shoots of first crop were placed in a paper bag and oven dried at $60^{\circ} \mathrm{C}$ until constant weight. Roots were clarified and colored with methyl blue $(0.05 \%)$ (Koske; Gemma, 1989) to assess the mycorrhizal colonization through gridline intersect method (Giovannetti, Mosse, 1980). To counts of AMF spores, soil samples were wet-sieved and centrifuged in water and saccharose (Gerdemann; Nicolson, 1963; Jenkins, 1964).

The microbial biomass carbon determined by the fumigation-extraction method (Vance; Brookes; Jenkinson, 1987) and phosphatase activity was quantified according to the method described by Tabatabai (1994), that fundaments on colorimetric determination of $\rho$-nitrophenol released from phosphatases' action, after soil incubation in $\rho$-nitrophenyl phosphate $\left(0.05 \mathrm{~mol} \mathrm{~L}^{-1}\right)$ solution. Soil total organic carbon (Corg) was determinated by potassium dichromate oxidation (Embrapa, 1997).

Were extracted two pools of glomalin-related soil protein, defined as total glomalin (T-GRSP) and easily extractable glomalin (EE-GRPS) according to methodology of Wright and Upadhyaya (1996). Briefly, autoclaving sample at $120^{\circ} \mathrm{C}$ for $30 \mathrm{~min}$ at $\mathrm{pH} 7.0$ in 20 $\mathrm{mM}$ citric acid resulting in easily extractable glomalin (EEGRPS). For total glomalin (T-GRPS), a sequential cycle of autoclaving at $120^{\circ} \mathrm{C}$ for $60 \mathrm{~min}$ each in $50 \mathrm{mM}$ citric acid at $\mathrm{pH} 8.0$ until the supernatant was clear/light yellow. The GRSPs concentration in the extracts was determined by Bradford assay (Bradford, 1976), using bovine serum albumin as a standard.

In order to quantify aggregation index, undeformed soil samples were collected in the $0-20 \mathrm{~cm}$ layer and then they were air-dried. The undeformed samples were splitted in the fracture points, then they were divided into $50 \mathrm{~g}$ duplicate subsamples. Then, subsamples were submitted to wetting by capillarity for $12 \mathrm{~h}$ in plastic cups with paper filter. Next, they were transferred to a set of sieves of 2.00, 0.25 and $0.106 \mathrm{~mm}$ mesh according to Embrapa (1997). Sieves were placed in Yoder apparatus (Yoder, 1936) and shook at 42 vertical oscillations per minute for $15 \mathrm{~min}$. Samples of each sieve were dried at $105^{\circ} \mathrm{C}$ and weighed.

From the data of wet sieving, it was calculated mean geometric diameter (MGD) and mean weighted diameter (MWD) of aggregates (mm), employing the equation of Kemper and Chepil (1965) as follow:

$$
M G D=\exp \left[\frac{\sum_{i=1}^{n} w i \log x i}{\sum_{i=1}^{n} w i}\right] \quad M W D=\sum_{i=1}^{n}(x i . w i)
$$

Where $w_{i}$ : proportion of each class relative to the total weight $(\mathrm{g})$ and $x_{i}$ : average mass of aggregates $(\mathrm{g})$.

Data was subjected to analysis of variance, Pearson correlation and means were compared by Scott-Knott test at $5 \%$ probability using the software $\mathrm{R}$.

\section{RESULTS AND DISCUSSION}

The shoot dry biomass production of plant species evaluated subject to the conditions of elimination and presence of AMF are in table 1.The results of shoot dry mass showed no significant interaction between the factors evaluated. In the second crop sequence, the grain yield of soybean ranged from 8.46 to $15.31 \mathrm{~g} \mathrm{pot}^{-1}$ and showed no differences between the treatments.

The inoculation with G. macrocarpum increased shoot biomass only in Stylosanthes spp. grown in sterilized soil (S-I), while there was no difference between treatments non-sterilized (NS-I and NI). Shoot dry mass of Brachiaria ruziziensis had no influence of inoculation with AMF, because the treatments inoculated (NS-I and S-I) did not differ of non-inoculated treatments (NS-NI and S-NI). Panicum maximum decreased 26 and $16 \%$ in shoot dry mass when inoculated (NS-I and S-I), respectively. Shoot biomass production of sorghum did not differ between treatments.

Both Stylosanthes spp. and Brachiaria ruziziensis produced more shoot dry mass when grown in nonsterilized soil (NS-NI and NS-I). These results demonstrate that the growth of these species is directly related to the presence of more active microbial community, which situation is not observed in sterilized treatments (S-NI and S-I), since the process of sterilization reduces soil microbial activity, even when inoculated with AMF.

Stylosanthes spp. showed high mycorrhizal dependency, since there was $91 \%$ reduction in shoot biomass in the non-inoculated treatment (S-NI) when compared to treatment inoculated (S-I) (Table 1). Carneiro et al. (1999) showed similar behavior increasing 307\% the production of shoot dry mass in Stylosanthes spp. inoculated with four species of AMF. The efficiency of AMF inoculation in Stylosanthes spp. was also reported by Lambais and Cardoso (1990), Souza et al. (1999) and Souza et al. (2000), corroborating the results found in this study.

Symbiosis with AMF promotes increased P uptake, increasing metabolism energy by higher production of ATP (Vadez et al., 1997), as occurs in Stylosanthes spp.. The process of biological $\mathrm{N}$ fixation demands much energy and hence is benefited by AMF association. Thus, it improves nutrition and plant growth directly and indirectly, by providing stimulus to $\mathrm{P}$ and $\mathrm{N}$ fixation, respectively. 
Arbuscular mycorrhizal fungusin microbial...

Table 1 - Effect of soil AMF inoculation on shoot dry mass of Panicum maximum, Brachiaria ruziziensis, Stylosanthes spp. and sorghum during the first crop in an Oxisol.

\begin{tabular}{|c|c|c|c|c|}
\hline Treatments & Panicum maximum & Brachiaria ruziziensis & Sorghum & Stylosanthes spp. \\
\hline & \multicolumn{4}{|c|}{ 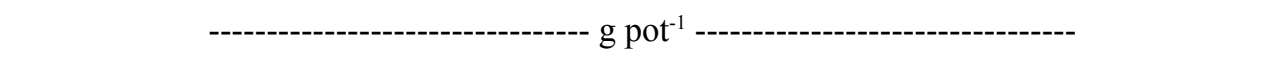 } \\
\hline S- NI & $26.37 \mathrm{a}$ & $27.16 \mathrm{~b}$ & $19.67 \mathrm{a}$ & $1.09 \mathrm{c}$ \\
\hline S- I & $22.66 \mathrm{~b}$ & $27.48 \mathrm{~b}$ & $25.43 \mathrm{a}$ & $13.32 \mathrm{~b}$ \\
\hline NS - NI & $29.82 \mathrm{a}$ & $32.85 \mathrm{a}$ & $27.57 \mathrm{a}$ & $35.16 \mathrm{a}$ \\
\hline NS- I & $23.69 \mathrm{~b}$ & $33.23 \mathrm{a}$ & $25.07 \mathrm{a}$ & $33.91 \mathrm{a}$ \\
\hline
\end{tabular}

S-NI: sterilized and non-inoculated soil; S-I: sterilized and inoculated soil; NS-NI: non-sterilized and non-inoculated soil; NS-I: non-sterilized and inoculated soil. Means followed by the same letter in the column do not differ by Scott-Knott test (5\%).

The decrease in shoot biomass in Panicum maximum observed in this study is due to the rate of root colonization and phosphate fertilization $\left(180 \mathrm{~kg} \mathrm{ha}^{-1}\right.$ of $\mathrm{P}_{2} \mathrm{O}_{5}$ ). Among the species studied, Panicum maximum had the lowest level of colonization, $33 \%$ (data not shown), probably due to high phosphate fertilizer and the greater ability to uptake nutrients promoted by its dense root system.

Even plants well supplied with phosphorus are not free of colonization. In this case, AMF can behave as a significant drain of photosynthates, contributing to the reduction of growth (Nóbrega et al., 2001), as confirmed by this study. This decrease occurs because the carbon cost of colonization is not compensated by the benefits of AMF symbiosis, since the plant does not benefit from this association, however, continues to allocate photosynthates to the fungus (Nogueira; Cardoso, 2000; Sena; Labate; Cardoso, 2004).

Only inoculation treatments affected microbial biomass carbon (Cmic), showing no significant $(p<0.05)$ effect of crop sequences or interaction (Figure 1a). In all crop sequences, higher content of Cmic occurred in the non-sterilized and inoculated (NA-I) soil, which was higher than the others. The Cmic in the treatments NS-NI and S-I did not differ among themselves and were higherto A- NI.

The contribution of inoculation (CI) with $G$. macrocarpum increased levels of Cmic. This contribution was more significant in non-sterilized soil that raised of $47 \%$ in the NS-I treatment compared to NS-NI. Thus, it appears that a synergistic effect exists between the FMA introduced (G. macrocarpum) with the indigenous AMF and other native microorganisms from soil. In the treatments sterilized (S-NI and S-I), the inoculation had similar effect, increasing the concentration in 37\%.

Microbial biomass represents a considerable reservoir of nutrients, and stands as the most active fraction of soil organic matter. It is responsible for the rapid flux and nutrient cycling, which has relevant importance in the nutrition and growth of plants (Moreira; Siqueira, 2006). AMF contribute to this increased biomass, since they represent the predominant fraction, around $30 \%$ of the soil microbial biomass (Rillig; Mummey, 2006). Furthermore, the mycorrhizal development represents a significant deposition of soil organic carbon through the development of external radical mycelium, spore production and glomalin, stimulation of root exudates (rhizodeposition) and mycorrhizosphere itself contributes to the increase of the bacterial population and other fungi in the soil (Andrade, Silveira, 2004; Johansson, Paul; Finlay, 2004; Rillig, Mummey, 2006). The rate Cmic/Corg shows that inoculation increases in $44 \%$ the microbial carbon in non-sterilized soil and 38\% in sterilized soil (Figure 1b).

This ratio reflects the ability to convert organic carbon into microbial carbon, Corg losses and stabilize the mineral fraction (Anderson; Domsch, 1989). In the present study, we found that this increased ratio coincides with the increase in the Cmic fraction. This effect is highly desired in agricultural systems, because this is a labile reserve of nutrients, highlighting the important role of AMF in the storage of carbon and other nutrients, which is extremely important for Cerrado soils.

The acid phosphatase activity did not change among crops successions. However, sterilization and inoculation treatments influenced the enzyme activity in soil (Figure 1c). Inoculation increased phosphatase activity in $21 \%$ in non-sterilized and inoculated soil (NSI) and differed significantly $(\mathrm{p}<\leq 0.05)$ from non-sterilized soil and non-inoculated soil (NI-NA). In the sterilized and inoculated treatment (S-I), the increase was $17 \%$ in relation to sterilized and non-inoculated treatment (S-NI), however there was no significant difference between them. This is due to the physiological modification of roots 
promoted by AMF hyphae and its extra root (Dakora; Phillips, 2002). Andrade and Silveira (2004) found that inoculated soybean plants presented direct changes in the supply of organic compounds to soil through rhizosphere, affecting microorganisms that live close to the roots, resulting in increased activity of soil microorganisms. Moreover, extrametrical mycelium plays an important role in excretion of acid phosphatase in soil (Su; Lin; Zhang, 2003). Therefore, our results reinforce synergistic effect of G. macrocarpum in association with indigenous AMF and soil microorganisms.

The total glomalin-related soil protein (T-GRSP) content ranged from 2.11 to $4.96 \mathrm{mg} \mathrm{kg}^{-1}$ and showed no significant differences $(p>0.05)$ between treatments. The T-GRSP is the glycoprotein fraction mostly located inside the aggregates and later deposited in the soil (Wright; Upadhyaya, 1998). Thus, it appears that this glomalin fraction is highly recalcitrant and does not suffer significant short-term effects (Sousa et al., 2011), which may have contributed to the results.

Easily extractable glomalin-related soil protein (EE-GRPS) content differed only in Panicum maximumas succession crop, where non-sterilized soil (NS-NI and NS-I) had a lower content than sterilized soils (S-NI and S-I) (Table 2). Among crop sequences only sterilized and non-inoculated treatment (S-NI) differed, with higher content in Panicum maximum/Panicum maximum and sorghum/soybean sequence.

The lower levels of EE-GRPS observed in nonsterilized treatments (NS-NI and NS-I) in the Panicum maximum occurred due to the high microbial activity of these soils, observed by high content of Cmic (Figure 1a). EE-GRPS is the soil glycoprotein fraction easily decomposed and deposited recently (Wright; Upadhyaya, 1998). Thus, the high microbial activity contributed to its degradation, resulting in the low levels found in this study corroborating with Rillig et al. (2005) and Khalili et al. (2011). Treseder and Turner (2007) point out that in soils where nutrients and carbon availability is limited, glomalin can be quickly mineralized, especially the fraction EEGRPS, resulting in its reduction, as shown by our results.

The average data of treatments showed that $9-16 \%$ of Corg is as EE-GRPS. Thereby, the management and land use that promote increase and/or maintain of GRPSs can provide and increase and storage carbon in the soil and, thus, mitigate $\mathrm{CO}_{2}$ emission (Báez-Pérez et al., 2010; Fokom et al., 2012) and improve soil structure.

The treatments affected mean geometric diameter (MGD) and mean weighted diameter (MWD) of aggregates. Largest MGD and MWD occurred in NSNI and NS-I treatments (Figure 2). Mean geometric diameter is an estimate of size of aggregate class with higher frequency and mean weighted diameter concerns the percentage of big aggregates (Castro Filho, Muzilli; Podanoschi, 1998). Crop sequence and their interaction with treatments showed no significant differences. We noted that indigenous AMF and other soil microorganisms present in the NS-NI treatment, when associated with $G$. macrocarpum (NS-I), increased the size of soil aggregate in relation to sterilized treatments (S-I and S-NI). (a)

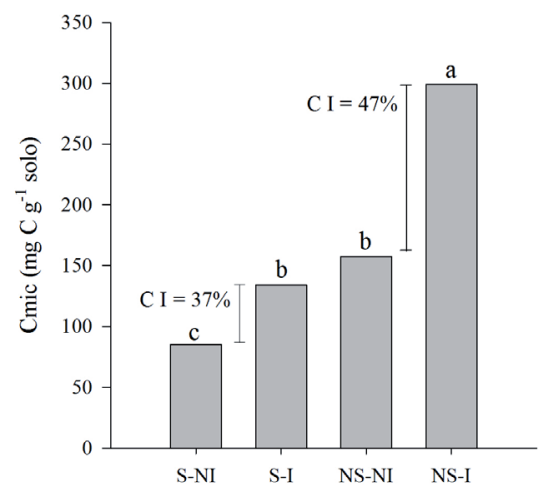

(b)

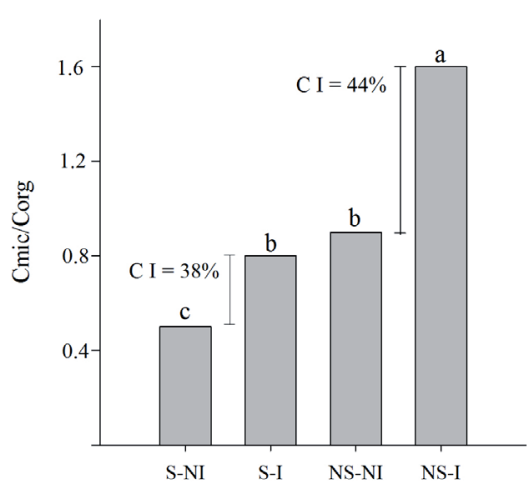

(c)

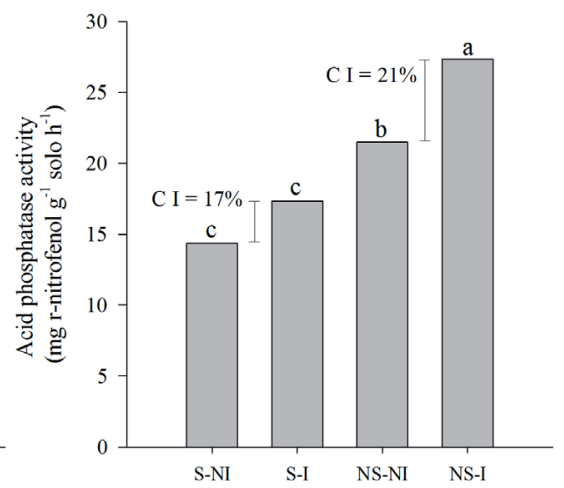

Figure 1 - Microbial biomass carbon (a), microbial biomass carbon (Cmic)/total organic carbon (Corg) ratio (b) and acid phosphatase activity (c) in a Cerrado Oxisol subjected to treatments studied. S-NI: sterilized and non-inoculated, S-I: sterilized and inoculated; NS-NI: non-sterilized and non-inoculated soil; NS-I: non-sterilized and inoculated soil. CI: contribution of inoculation with G. macrocarpum [(Inoculated - non-inoculated / non-inoculated)* 100]. Bars with the same letter do not differ by Scott Knott test (5\%).

Ciênc. Agrotec., Lavras, v.38, n. 1, p.34-42, jan./fev., 2014 
Table 2 - Easily extractable glomalin-related soil protein (EE-GRPS) from a Cerrado Oxisol subjected to AMF inoculation.

\begin{tabular}{lcccc}
\hline Treatments & $\begin{array}{c}\text { Panicum maximum/ } \\
\text { Panicum maximum }\end{array}$ & $\begin{array}{c}\text { Brachiaria ruziziensis/ } \\
\text { Soybean }\end{array}$ & $\begin{array}{c}\text { Sorghum/ } \\
\text { Soybean }\end{array}$ & $\begin{array}{c}\text { Stylosanthes spp./ } \\
\text { Soybean }\end{array}$ \\
\hline & & $-1.78 \mathrm{aB}$ & $2.26 \mathrm{aA}$ & $1.47 \mathrm{aB}$ \\
S - NI & $3.49 \mathrm{aA}$ & $3.17 \mathrm{aA}$ & $2.10 \mathrm{aA}$ & $2.51 \mathrm{aA}$ \\
S - I & $3.80 \mathrm{aA}$ & $1.29 \mathrm{aA}$ & $1.97 \mathrm{aA}$ & $2.03 \mathrm{aA}$ \\
NS - NI & $1.79 \mathrm{bA}$ & $2.02 \mathrm{aA}$ & $1.99 \mathrm{aA}$ & $2.33 \mathrm{aA}$ \\
NS - I & $1.59 \mathrm{bA}$ & &
\end{tabular}

S-NI: sterilized and non-inoculated soil; S-I: sterilized and inoculated soil; NS-NI: non-sterilized and non-inoculated soil; NS-I: non-sterilized and inoculated soil. Means followed by the uppercase letter in rows and lowercase in columns do not differ by the Scott-Knott test (5\%).

(a)

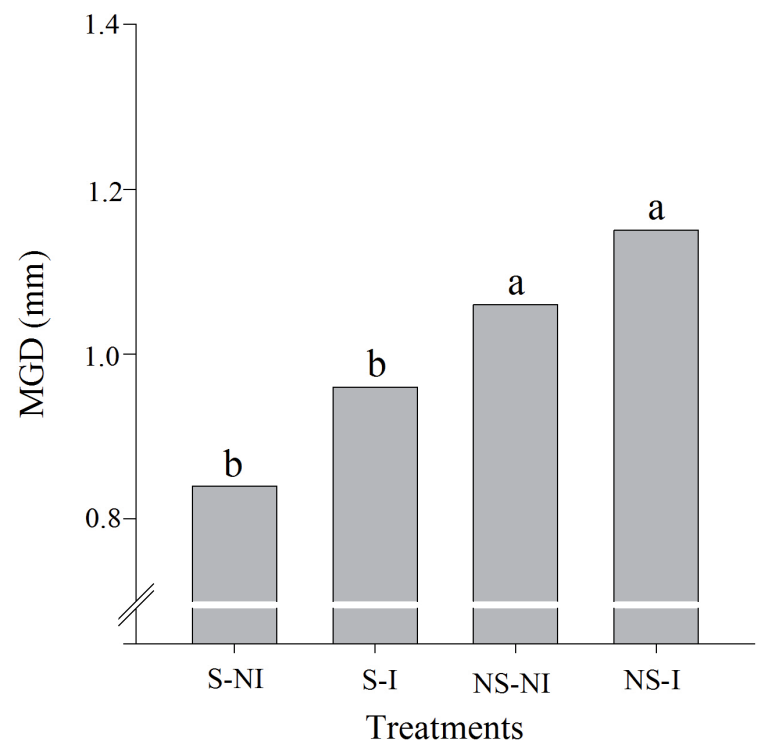

(b)

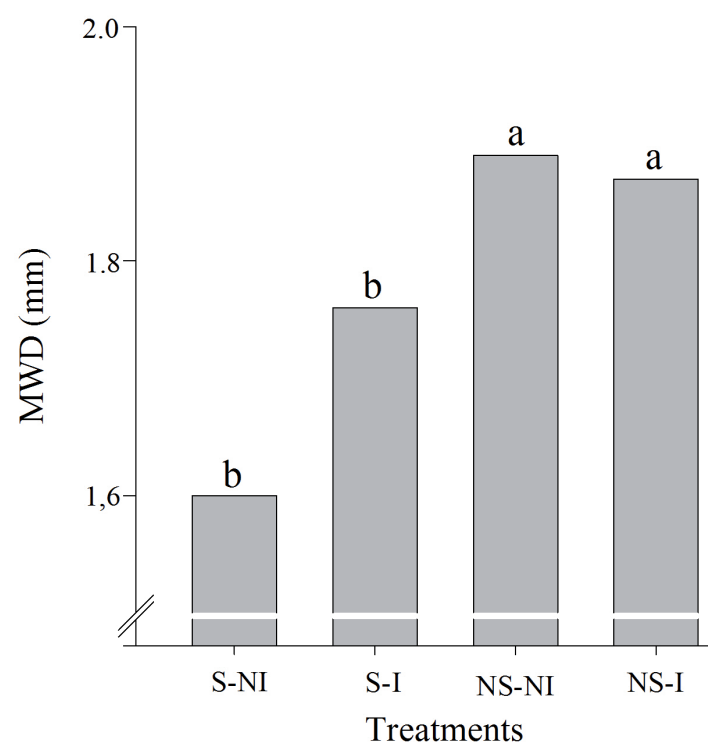

Figure 2 - Mean geometric diameter (MGD) and mean weight diameter (MWD) obtained by wet sieving of aggregates in Cerrado Oxisol subjected AMF inoculation. S-NI: sterilized and non-inoculated, S-I: sterilized and inoculated; NSNI: non-sterilized and non-inoculated, NS-I: non-sterilized and inoculated soil. Bars followed by the same letter do not differ by the Scott Knott test (5\%).

The bigger and more preserved microbial biomass in non-sterilized soil presents distinct functional characteristics and plays an essential role in soil aggregation (Six et al., 2004), as presented our results. Among soil microorganisms, AMF are the most important aggregation mediators, since they are the dominant component of the microbial biomass (Rillig, Steinberg, 2002; Borie, Rubio; Morales, 2008). We confirmed this affirmative in our study through outcomes presented and the positive and significant correlation between $\mathrm{Cmic}$ with MGD $(\mathrm{r}=0.92, p<0.01)$ and MWD $(\mathrm{r}=0.73, p<0.01)$.

Larger microbial activity results in polysaccharides production and other materials by the decomposition process of organic compounds splitted, which cements soil particles promoting the aggregation. Therefore, the combined action of mechanical joining by AMF hyphae, with stimulus of microbial biomass, enhances the release of cementing products (polysaccharides and glycoprotein), 
improving aggregation indexes by increased stability aggregates(Helgason, Walley; Germida, 2010; CaesarTonThat et al., 2011; Caruso, Rillig, 2011). The elimination of microorganisms by sterilization reduced soil microbial biomass and indigenous AMF. It affected soil aggregation process, which was not recovered after inoculation with G. macrocarpum.

Our findings showed evident direct and indirect benefits of AMF to improve soil structure. These benefits have remarked importance in the maintenance of soil aeration and porosity, important factors to plants and microorganisms, moreover, increase water infiltration and resistance the erosive processes (Caesar-TonThat et al., 2011). We observed that crop sequence had no influence on microbial activity and soil aggregation. However, the inoculation with G. macrocarpum associated with indigenous AMF and soil microbiota increased soil aggregation. Thus, the other effects reported also shows the beneficial effects of inoculation, which reflects in soil structure improvement and, hence, to the sustainability of agroecosystems.

\section{CONCLUSIONS}

Among crop sequence, only Stylosanthes spp. benefited from the inoculation with G. macrocarpum.

Inoculation with G. macrocarpum increased microbial biomass carbon and soil acid acida phosphatase activity.

Soil microbiota associated with indigenous AMF, and inoculation of G. macrocarpum increased mean geometric diameter and mean weighted diameter of soil aggregates.

Crop sequence showed no effects in microbial biomass carbon, acid phosphatase activity, mean geometric diameter and mean weighted diameter of soil aggregates.

\section{ACKONWLEDGMENTS}

This work is part of the first author's requirements to obtain title of M.Sc. in Agronomy at Federal University of Goiás, Campus Jataí. The first author thank to CAPES for assistantship. The authors thank the Conselho Nacional de Desenvolvimento Científico e Tecnológico (CNPq) for financial support (Project 559682/2009-3) and research grant (308207/2011-4).

\section{REFERENCES}

ANDERSON, T. H.; DOMSCH, K. Ratios of microbial biomass carbon to total organic carbon in arable soils. Soil Biology and Bochemistry, 21(4): 471-479, 1989.
ANDRADE, S. A. L.; SILVEIRA, A. P. D. Biomassa e atividade microbianas do solo sob influência de chumbo e da rizosfera da soja micorrizada. Pesquisa Agropecuária Brasileira, 39(2): 1191-1198, 2004.

BÁEZ-PÉREZ, A. et al. Glomalina y secuestro de Carbono en tepetates cultivados, Agrociencia. 44(5):517-529, 2010.

BORIE, F.; RUBIO, R.; MORALES, A. Arbuscular mycorrhizal fungi and soil aggregation. Journal of Soil Science and Plant Nutrition, 8(2):9-18, 2008.

BRADFORD, M. M. A rapid and sensitive method for the quantitation of microgram quantities of protein utilizing the principle of protein-dye binding. Analytical biochemistry, 72(1):248-254, 1976.

CAESAR-TONTHAT, T. et al. Long-term tillage and cropping effects on microbiological properties associated with aggregation in a semi-arid soil. Biology and Fertility of Foils, 47(2):157-165, 2011.

CARNEIRO, M. A. C. et al. Efeitos da inoculação de fungos micorrízicos arbusculares e da aplicação de fósforo no estabelecimento de forrageiras em solo degradado. Pesquisa Agropecuária Brasileira, 34(9):1669-1667, 1999.

CARUSO, T.; RILLIG, M. C. Direct, positive feedbacks produce instability in models of interrelationships among soil structure, plants and arbuscular mycorrhizal fungi. Soil Biology and Biochemistry, 43(6):11981206, 2011.

CASTRO FILHO, C. D.; MUZILLI, O.; PODANOSCHI, A. Estabilidade dos agregados e sua relação com o teor de carbono orgânico num Latossolo Roxo distrófico, em função de sistemas de plantio, rotações de culturas e métodos de preparo das amostras. Revista Brasileira de Ciência do Solo, 22(3):527-538, 1998.

CORDEIRO, M. A. S. et al. Colonização e densidade de esporos de fungos micorrízicos em dois solos do cerrado sob diferentes sistemas de manejo. Pesquisa Agropecuária Tropical, 35(3):147-153, 2005.

DAKORA, F. D.; PHILLIPS, D. A. Root exudates as mediators of mineral acquisition in low-nutrient environments. Plant and Soil, 245(1):35-47, 2002. 
EMPRESA BRASILEIRA DE PESQUISA AGROPECUÁRIA -EMBRAPA. Manual de métodos de análise de solo. Rio de Janeiro: Embrapa - Centro Nacional de Pesquisa de Solos, 1997.

FERREIRA, D. A.; CARNEIRO, M. A. C.; SAGGINJUNIOR, O. J. Fungos micorrízicos arbusculares em um Latossolo Vermelho sob manejos e usos no cerrado. Revista Brasileira de Ciência do Solo, 1:51-61, 2012.

FOKOM, R. et al. Glomalin related soil protein, carbon, nitrogen and soil aggregate stability as affected by land use variation in the humid forest zone of south Cameroon. Soil and Tillage Research, 120:69-75, 2012.

GERDEMANN, J.; NICOLSON, T. H. Spores of mycorrhizal Endogone species extracted from soil by wet sieving and decanting. Transactions of the British Mycological Society, 46(2):235-244, 1963.

GIOVANNETTI, M.; MOSSE, B. An evaluation of techniques for measuring vesicular arbuscular mycorrhizal infection in roots. New Phytologist, 84(3):489-500, 1980.

GONZÁLEZ-CHÁVEZ, M.; GUTIÉRREZ-

CASTORENA, M.; WRIGHT, S. Hongos micorrízicos arbusculares en la agregación del suelo y su estabilidad. Terra Latinoamericana, 22(4):507-514, 2004.

HELGASON, B.; WALLEY, F.; GERMIDA, J. No-till soil management increases microbial biomass and alters community profiles in soil aggregates. Applied Soil Ecology, 46(3):390-397, 2010.

JENKINS, W. R. A. A rapid centrifugal-flotation technique for separating nematodes from soil. Plant Disease Reporter, 48(9):692, 1964.

JOHANSSON, J. F.; PAUL, L. R.; FINLAY, R. D. Microbial interactions in the mycorrhizosphere and their significance for sustainable agriculture. FEMS Microbiology Ecology, 48(1):1-13, 2004.

KEMPER, W.; CHEPIL, W. Size distribution of aggregates. In: BLACK, C. A. (Ed.). Methods of Soil Analysis. Part 1. Physical and Mineralogical Properties, Including Statistics of Measurement and Sampling. Madison: American Society of Agronomy / Soil Society of America, 1965, p. 499-510.
KHALILI, B. et al. Does cultivation influence the content and pattern of soil proteins? Soil and Tillage Research,111(2):162-167, 2011.

KLIRONOMOS, J. N. et al. The influence of arbuscular mycorrhizae on the relationship between plant diversity and productivity. Ecology Letters, 3(2):137-141, 2000

KOSKE, R.; GEMMA, J. A modified procedure for staining roots to detect VA mycorrhizas. Mycological Research, 92(4):486-488, 1989.

LAMBAIS, M.; CARDOSO, E. Response of Stylosanthes guianensis to endomycorrhizal fungi inoculation as affected by lime and phosphorus applications. Plant and Soil, 129(2):283-289, 1990.

MIRANDA, J. D.; VILELA, L.; MIRANDA, L. D. Dinâmica e contribuição da micorriza arbuscular em sistemas de produção com rotação de culturas. Pesquisa Agropecuária Brasileira, 40(10):1005-1014, 2005.

MOREIRA, F. M. S.; SIQUEIRA, J. O. Microbiologia e bioquímica do solo. 2 ed. Lavras: Universidade Federal de Lavras, 2006, 626 p.

NÓBREGA, J. C. A. et al. Fosfato e micorriza na estabilidade de agregados em amostras de latossolos cultivados e não-cultivados. Pesquisa Agropecuária Brasileira, 36(11):1425-1435, 2001.

NOGUEIRA, M.; CARDOSO, E. Produção de micélio externo por fungos micorrízicos arbusculares e crescimento da soja em função de doses de fósforo. Revista Brasileira de Ciência do Solo, 24(2):329-338, 2000.

PURIN, S.; RILLIG, M. C. The arbuscular mycorrhizal fungal protein glomalin: limitations, progress, and a new hypothesis for its function. Pedobiologia, 51(2):123130, 2007.

RILLIG, M. C. Arbuscular mycorrhizae, glomalin, and soil aggregation. Canadian Journal of Soil Science, 84(4):355-363, 2004

RILLIG, M. C. et al. Microbiota accompanying different arbuscular mycorrhizal fungal isolates influence soil aggregation. Pedobiologia, 49(3):251-259, 2005. 
RILLIG, M. C.; MUMMEY, D. L. Mycorrhizas and soil structure. New Phytologist, 171(1):41-53, 2006.

RILLIG, M. C.; STEINBERG, P. D. Glomalin production by an arbuscular mycorrhizal fungus: a mechanism of habitat modification? Soil Biology and Biochemistry, 34(9):1371-1374, 2002.

SENA, J.; LABATE, C.; CARDOSO, E. Caracterização fisiológica da redução de crescimento de mudas de citros micorrizadas em altas doses de fósforo. Revista Brasileira de Ciência do Solo, 28(05):827-832, 2004.

SIQUEIRA, J.; KLAUBERG-FILHO, O.; NOVAIS, R. Micorrizas arbusculares: a pesquisa brasileira em perspectiva. Tópicos em Ciência do Solo, 1:235-264, 2000.

SIX, J. et al. A history of research on the link between (micro) aggregates, soil biota, and soil organic matter dynamics. Soil and Tillage Research, 79(1):7-31, 2004.

SOUSA, C. S. et al. Influências da temperatura de armazenamento e de extratores na determinação de glomalina em solos paraibanos. Revista Ciência Agronômica, 42(4):837-841, 2011.

SOUSA, D. M. G.; LOBATO, E. Cerrado: correção do solo e adubação. Planaltina: Embrapa Cerrados, 2004, $416 \mathrm{p}$.

SOUZA, R. et al. Micorriza e fósforo no crescimento de Brachiaria brizantha e Stylosanthes guianensis em solo de baixa fertilidade. 1. Produção de matéria seca e proteína bruta. Pasturas Tropicales, 21(3):19-23, 1999.

SOUZA, R. D. et al. Effects of mycorrhizas and phosphorus on growth of Andropogon gayanus and Stylosanthes guianensis grown under water stress in a Dystrophic dark-red Latosol. Pasturas Tropicales, 22(2):42-46, 2000.
STÜRMER, S. L.; SIQUEIRA, J. O. Species richness and spore abundance of arbuscular mycorrhizal fungi across distinct land uses in Western Brazilian Amazon. Mycorrhiza, 21(4):255-267, 2011.

SU, Y. B.; LIN, F. S.; ZHANG, X. L. L. Effect of arbuscular mycorhiza fungi on phosphatase activities and soil organic phosphate content in clover rhizosphere, Soils, 35(4):334-338, 2003.

TABATABAI, M. Soil enzymes. In: WEAVER, R. W. A.; BOTTOMLY, P. S. (Ed.). Methods of Soil Analysis: Part 2 - Microbiological and Biochemical Properties. Madison: Soil Science Society of America, 1994, p. 775-833.

TRESEDER, K. K.; TURNER, K. M. Glomalin in ecosystems. Soil Science Society of America Journal, 71(4):1257-1266, 2007.

VADEZ, V. et al. Utilization of the acetylene reduction assay to screen for tolerance of symbiotic $\mathrm{N}_{2}$ fixation to limiting $\mathrm{P}$ nutrition in common bean. Physiologia Plantarum, 99(2):227-232, 1997.

VANCE, E.; BROOKES, P.; JENKINSON, D. An extraction method for measuring soil microbial biomass C, Soil biology and Biochemistry, 19(6):703-707, 1987.

WRIGHT, S.; UPADHYAYA, A. A survey of soils for aggregate stability and glomalin, a glycoprotein produced by hyphae of arbuscular mycorrhizal fungi. Plant and soil, 198(1):97-107, 1998.

WRIGHT, S. F.; UPADHYAYA, A. Extraction of an abundant and unusual protein from soil and comparison with hyphal protein of arbuscular mycorrhizal fungi. Soil Science, 161(9);575-586, 1996.

YODER, R. E. A direct method of aggregate analysis of soils and a study of the physical nature of erosion losses. Agronomy Journal, 28(5):337-351, 1936. 